\title{
P 312
}

勤労者のストレス対処行動と精神健康度との関連

○石崎潤子 ${ }^{1}$ 、田中克俊 ${ }^{2}$ 、松井満治 ${ }^{2}$ 、高安英樹 ${ }^{2}$ 1 （株）東芝 マイクロエレクトロニクスセンター

2 (株) 東芝 勤労福祉センター保健支援業務部

はじめに ますます加速する技術革新、サ 一ビス経済化の進展などにより、職場の労 働環境、作業態様が変化してきていること に伴い、ストレスを感じる労働者も増加し てきている。1997 年の「労働者健康状 況調査報告」によると、自分の仕事や職業 生活での「強い不安・悩み・ストレスがあ る」とする割合は、63\%（男性 $64 \%$ 、 女性 $60 \%$ ）で 82 年の $51 \%$ と比べ、大 幅に上昇している。強い不安、悩み、スト レスの原因は、「職場の人間関係の問題」 が $46 \%$ と最も高くなっており、メンタル ヘルス活動においても、精神健康度の低い 労㗢者のケアはもとより、予防的にアプロ 一チすることがますます重要になってき ている。プロセス論的立場から見たストレ ス対処行動は、メンタルヘルスに関する重 要な予防的な介入変数であると考えられ ている。

目的勤労者を対象として対処行動と精 神健康度との関連について検討し、メンタ ルヘルスの予防として対処行動へのアプ ローチへの有効性について考察する。

対象 総合電機メ一カーに勤務する勤労者 で、調査への参加に同意した $2 ， 343$ 名 (男性 1，361 名, 女性982 名)

方法 2000 年度定期健康診断後の健 康支援時に、対処行動尺度（中野，47 項 目版)、G H Q ( 12 項目版)についての質 問票調査を行った。対処行動尺度の下位尺 度得点と $\mathrm{GHQ}$ 得点との相関係数の他、 $\mathrm{G}$ $\mathrm{HQ}$ 得点を目的変数、対処行動尺度得点や 基本属性を説明変数とした重回帰分析を
行い身体健康度と対処行動下位尺度との 関連を調べた。

結果 今回の対処行動尺度は、先行研究で 示されている結果に従い、(1)問題解決焦点 型の対処行動 (2)情緒焦点型の対処行動 (3)周囲に支援を求める対処行動の 3 つの 下位尺度に分けて解析を行ったが、これは 今回の結果に基づく因子分析の結果とも 矛盾しなかった。G HQ 総得点と 3 つの下 位尺度との相関は、それぞれ-. $25, .18$ ， -. 12 であり統計学的に有意であった。ま た、男女別に $\mathrm{GHQ}$ 総得点を目的変数とし た重回帰分析を行った結果、男女とも問題 焦点型対処行動と情緒焦点型の対処行動 得点が $\mathrm{GHQ}$ 得点と有意な関連を示した。 結論 $\mathrm{GHQ}$ 得点と対処行動尺度得点と の間に統計学的に有意な関連が示され、精 神健康度と対処行動パターンには関連が あることが示された。実際には、対処行動 と精神健康度との間には他の様々な変数 や構成概念を含んだ複雑な因果関係や相 互関係が存在すると考えられ、今後 S E M 等を用いたより高次のモデルを構築して いくことで、対処行動の変容も含めた具体 的なメンタルヘルス予防プログラム作り が可能になると考えられた。 